Available online at: http://journals.rsfpress.com/index.php/ijmesh

International Journal of Management, Entrepreneurship, Social Science and Humanities (IJMESH)

ISSN 2580-0981 (online)

Volume 3 Number 2 (2020): 28-36

\title{
Managerial Roles: Intuitions of the Academic Institution Employees, an evidence from the universities in Ozamiz City
}

\author{
Anna C. Bocar \\ Faculty of Business and Management Studies, Gulf College
}

\begin{abstract}
Within this study, we want to determine the extent of academic administrators' managerial roles in a certain university, because their role in any academic institution is the most significance to lead the employees and middle managers. Once the administrators do the proper and appropriate management, the organization's goals will be attained. We employed the descriptive survey method, and used the rating of administration's managerial roles implementation, as one of our measures in our questionnaires. We formulated a qualitative scale, and each one has its corresponding verbal interpretation. In addition, we propose a hypothetical mean range, which is the assigned numeric value to strengthen and validate each of the particular qualitative extent. We found that the academic administrators manifested their managerial roles are at a great degree; confirming the interview with the nonteaching staff and the academic administrators themselves. We conclude that although the academic administrators manifested their capabilities in performing their managerial roles to attain the goals of the university, still, there were certain areas that they needed to develop, such as to enhance network with other institutions and community agency, to confine subordinate's workload with a dedication for official duties.
\end{abstract}

Keywords: Interpersonal, Conceptual, Technical Managerial Roles

This is an open access article under the CC-BY-NC license

\section{INTRODUCTION}

Today, education administrators find themselves leading the organizations and groups across a rapidly shifting perspective toward new destinations. These professionals are increasingly more diverse and challenged to deal with undefined problems, grapple with theoretical and emotional issues, and make decisions so new that the organizational consequences are unknown. Furthermore, educational administrators must help individuals and groups make sense and increased meaning in often fragmented, overwhelming, and fast-moving situations characteristic of the new era (March \& Simon, 2004). In the face of these demands, academic administrators of a university, which is the setting of the research, do realize that they can no longer rely on traditional management techniques to satisfy the requirements of their roles - they must draw on a deeper source of guidance, strength, and influence. This can be attained by revisiting their roles to enable them to create suitable structures that adapt to the changing landscape of the academe. This research examines the university administrators' roles to be able to cope with the new trends of the future. Hence, this can be completed through the participation of the employees in the said university. 


\section{LITERATURE REVIEW}

Cunningham \& Cordeiro (2012) articulated that "academic leaders today cannot be successful without having a broad understanding of the social, political, and economic dynamics that influence and are shaped by global education". Leaders in academic institutions are having the same role as the managers in a company who are producing goods. In the academe, the leaders are not only responsible for their subordinates but also to the students. However, these subordinates would become effective and efficient in their performance and could produce globally competitive graduates when their managers are operationally active. Managers must understand all elements of the company's administration (Campbell, Corbally, and Nystraud, 2010) and create a shared vision of excellence that can be translated into practice. They must also raise employees' expectations for support, continued improvement, rewards, and recognition in all aspects of excellence.

Drucker (2002) enunciated that the quality of the administration depends on the effectiveness of the company's managers to be able to respond to a diverse group of employees and pressures as they continuously work to improve the company. The call is for managers with administrative know-how who understand the social, economic, and human demands, the government and community program, as well as the professional expectations and responsibilities of the work. In the academic institution, educational administration practice is a blending of knowledge, practice, ethics, tradition, and new vision. There is no one approach that will provide a complete explanation for administrative practitioners in evaluation (Lunenburg \& Ornstein, 2004). The challenge for the administrators is to find ways to integrate the various perspectives, values, and approaches so as to improve the outcomes of the evaluation and the functioning of educational organizations.

The role of a manager is essential for an administrator and is probably the most important aspect of all leadership functions. Katz \& Khan (2003) divided management roles into three major areas: the first is the technical role. It involves good planning, organizing, coordinating, supervising, and controlling techniques. Technical roles assumed by an administrator deals with specialized knowledge, procedures, and techniques to accomplish the task. It involves the understanding of and proficiency in the performance of specific tasks. Generally, assuming a technical role includes mastery of the methods, techniques, and facilities involved in specific functions such as finance, research, and others. Furthermore, the role calls for specialized knowledge, analytical ability, and the competent use of techniques to solve problems in a specific description. The second type of managerial role which administrators assumed is interpersonal relations. This role normally deals with human relations and people management skills, good motivation, and morale building activities. This role of an administrator focuses on his ability to understand the feelings and attitudes of others and to establish cooperative work relationships. It is the administrator's function to work with and through other people and to work effectively as a group member. This is normally demonstrated by the way an administrator relates to other people, including the ability to motivate, facilitate, coordinate, lead, and resolve conflicts. An administrator who assumes such a role tends to allow subordinates to express themselves without fear of ridicule and improve participation. The third managerial role assumed by the university administrators is the conceptual role. This refers to the manager's responsibility, which emphasizes knowledge and technical skills. It involves developing and using ideas as well as concepts to solve complex problems. It is the 
cognitive role that sets the organization as a whole and the relationship among its parts. The conceptual role involves the manager's thinking, facts processing, and planning activities. In short, it is the capacity of the manager to think strategically, taking a broad, long-term view (Katz et al.,2003).

According to Peterson and Deal (2013), the administrators communicate core values, behaviors, and expectations in their everyday work and interaction with peers, subordinates, and heads of different departments. Administrators then serve as a balancing act between self and others. An effective administrator recognizes his or her personality and how operational factors or daily tasks affect his or her relationship with others. The study is conducted to determine the extent of managerial roles' manifestation as perceived by the employees in one of the universities in Ozamiz City.

\section{METHODOLOGY}

The process involved the use of the descriptive survey method of research. The researcher made questionnaires and was used in data collection. The purpose of this study was to look into the extent of managerial roles manifested by the university's administrator as assessed by the one hundred seven employees (administrators themselves, teaching, and the nonteaching staff). The setting of the study was in one of the universities in Ozamiz City, Philippines. The weighted mean is utilized in this paper. A qualitative measurement was formulated with each specific verbal interpretation. The complete-scale is shown below:

Table 1: Qualitative Measurement and Verbal Interpretation

\begin{tabular}{|c|c|l|l|l|}
\hline $\begin{array}{c}\text { Numeric } \\
\text { Value }\end{array}$ & Mean Range & $\begin{array}{c}\text { Qualitative } \\
\text { Measurement }\end{array}$ & & \multicolumn{1}{|c|}{$\begin{array}{c}\text { Verbal Interpretation } \\
\text { means that the academic } \\
\text { administrators }\end{array}$} \\
\hline 1 & $1.00-1.75$ & Never & $\mathrm{N}$ & do not manifest the role \\
\hline 2 & $1.76-2.50$ & Less Extent & LE & $\begin{array}{l}\text { manifest the role in a few instances } \\
\text { only }\end{array}$ \\
\hline 3 & $2.51-3.25$ & Great Extent & GE & $\begin{array}{l}\text { manifest the role in the majority of the } \\
\text { cases }\end{array}$ \\
\hline 4 & $3.26-4.00$ & $\begin{array}{l}\text { Very } \\
\text { Great Extent }\end{array}$ & VGE & manifest the role in all cases \\
\hline
\end{tabular}

To validate the interpretation, a numeric value was assigned to assure that the answers of the respondents are certainly their choices, and an assumed mean range is also provided in order to attain the intended meaning of each response.

\section{RESULTS}

This part highlights the result of the study, and these are presented in the succeeding tables.

1. Technical Managerial Role of the Academic Administrators

Table 2 reveals the data on the extent to which the university's academic administrators manifested their technical role as managers. Generally, as shown by the factor average of 3.33 , the administrators were 
found to exercise their technical role to a very great extent. Moreover, the respondents rated the two (No. 3 and 4) of the six inventory items to a great extent. This can be assumed that the three groups of respondents feel the same way in these two items.

One of the ways to be updated with the new trends and methodologies in the learning process, the administrators must establish networks with other institutions and community agencies $(\mu=3.12)$. According to Wright (2002), this is considered an effective strategy of broadening the administrators' circle of contacts and forging linkages to promote student employability/marketability. The item average of 3.14 signifies that the administrators avoided giving assignments to their subordinates, which were not within their job. With the rating given, it can be interpreted that the subordinates with the appropriate abilities were appointed and tasked to perform the specific job to a great extent.

Table 2: Technical Managerial Role of the Academic Administrators

\begin{tabular}{|c|c|c|c|c|c|c|c|c|}
\hline \multirow[t]{2}{*}{$\begin{array}{c}\text { Inventory Items for } \\
\text { Technical Managerial Roles }\end{array}$} & \multicolumn{2}{|c|}{$\begin{array}{c}\text { Teaching } \\
\text { Staff }\end{array}$} & \multicolumn{2}{|c|}{ Administrators } & \multicolumn{2}{|c|}{$\begin{array}{c}\text { Nonteaching } \\
\text { Staff }\end{array}$} & \multicolumn{2}{|c|}{$\begin{array}{c}\text { Item } \\
\text { Average }\end{array}$} \\
\hline & $\mu$ & INT & $\mu$ & INT & $\mu$ & INT & $\mu$ & INT \\
\hline $\begin{array}{c}\text { 1. Set good examples to achieve } \\
\text { organizational goals }\end{array}$ & 3.01 & GE & 3.55 & VGE & 3.91 & VGE & 3.49 & VGE \\
\hline $\begin{array}{l}\text { 2. Keep self-abreast with current } \\
\text { relevant issues }\end{array}$ & 3.04 & GE & 3.50 & VGE & 3.45 & VGE & 3.33 & VGE \\
\hline $\begin{array}{l}\text { 3. Network with other institutions } \\
\text { and community agency }\end{array}$ & 3.13 & GE & 3.10 & GE & 3.12 & GE & 3.12 & GE \\
\hline $\begin{array}{l}\text { 4. Confine subordinates' workload } \\
\text { to official duties only }\end{array}$ & 3.08 & GE & 3.20 & GE & 3.15 & GE & 3.14 & GE \\
\hline $\begin{array}{l}\text { 5. Hold consultative meetings and } \\
\text { socials }\end{array}$ & 3.05 & GE & 3.45 & VGE & 3.91 & VGE & 3.47 & VGE \\
\hline 6. Plan activities ahead of time & 2.99 & GE & 3.65 & VGE & 3.64 & VGE & 3.43 & VGE \\
\hline FACTOR AVERAGE & 3.05 & GE & 3.41 & VGE & 3.53 & VGE & 3.33 & VGE \\
\hline
\end{tabular}

Source: Respondents 'Answer on the Researcher made Questionnaire

On the other hand, four of the six inventory items were generally rated by the respondents to a very great extent. The average of these four items demonstrated the fact that the administrators established an upright technical attitude to triumph in their endeavors; however, specifically, it can be noticed that the teaching staff rated these four items at a scale lower than such rating, which is a great extent.

The administrators, to a very great extent, set good examples to achieve organizational goals. This means that the administrators took it upon themselves to act as a role model in their individual workgroups $(\mu=3.49)$. They also work through and with their subordinates to ensure that the institution's goals are attained. The administrators were deemed to keep themselves abreast with current relevant issues, which would have a significant impact on their department's operations $(\mu=3.33)$. They actively engaged in retooling sessions and other developmental activities like attending seminars, conferences, and others to keep pace with changes in the academic community (F. Ejercito, Interview, February 4, 2016). To foster the so-called "esprit de corps", the administrators regularly held meetings and sponsor social gatherings when the need arises to enhance team spirit and harmony, leading to organizational unity (J. 
Betonio, Interview, May 7, 2016). It is evidenced in the respondents' rating $(\mu=3.47)$ that the administrators hold consultative meetings and socials with their subordinates. Lastly, the administrators were deemed to plan their activities ahead of time, as shown by the item average of 3.43. This means that they do their tasks to minimize delays in the implementation and completion while at the same time evaluating the implications of the overall organizational strategy for the activities of the workgroup to a very great extent.

\section{Interpersonal Managerial Role of the Academic Administrators}

The data on the extent to which the academic administrators of the university manifested their interpersonal roles are displayed in table 3. Based on the results, it can be observed that the respondents rated the items as regards to the interpersonal role of the administrators with varied qualitative scales.

Table 3: Interpersonal Managerial Role of the Academic Administrators

\begin{tabular}{|l|c|c|c|c|c|c|c|c|}
\hline \multirow{2}{*}{$\begin{array}{l}\text { Inventory Items for } \\
\text { Interpersonal Roles }\end{array}$} & \multicolumn{2}{|c|}{$\begin{array}{c}\text { Teaching } \\
\text { Staff }\end{array}$} & \multicolumn{2}{c|}{$\begin{array}{c}\text { Admi } \\
\text { nistrators }\end{array}$} & \multicolumn{2}{c|}{$\begin{array}{c}\text { Nonteaching } \\
\text { Staff }\end{array}$} & \multicolumn{2}{c|}{$\begin{array}{c}\text { Item } \\
\text { Average }\end{array}$} \\
\cline { 2 - 10 } & $\mu$ & INT & $\mu$ & INT & $\mu$ & INT & $\mu$ & INT \\
\hline $\begin{array}{l}\text { 1. Promote open communication } \\
\text { among subordinates, peers, and } \\
\text { superiors. }\end{array}$ & 3.18 & GE & 3.58 & VGE & 3.91 & VGE & 3.56 & VGE \\
\hline $\begin{array}{l}\text { 2. Demonstrate fairness in } \\
\text { dealing with subordinates }\end{array}$ & 2.36 & LE & 3.50 & VGE & 3.64 & VGE & 3.17 & GE \\
\hline $\begin{array}{l}\text { 3. Take full responsibility for } \\
\text { one's action }\end{array}$ & 3.04 & GE & 3.00 & GE & 3.45 & VGE & 3.16 & GE \\
\hline $\begin{array}{l}\text { 4. Provide an alternative } \\
\text { approach in solving the problem }\end{array}$ & 3.18 & GE & 3.25 & GE & 3.73 & VGE & 3.39 & VGE \\
\hline $\begin{array}{l}\text { 5. Accept limitations and } \\
\text { welcome constructive } \\
\text { criticisms to enhance one's } \\
\text { management }\end{array}$ & 3.28 & VGE & 3.47 & VGE & 3.73 & VGE & 3.49 & VGE \\
\hline $\begin{array}{l}\text { 6. Inspire subordinates and peers } \\
\text { to enhance their personal and } \\
\text { professional careers. }\end{array}$ & 3.04 & GE & 3.55 & VGE & 3.91 & VGE & 3.50 & VGE \\
\hline FACTOR AVERAGE & 3.01 & GE & 3.39 & VGE & 3.72 & VGE & 3.37 & VGE \\
\hline
\end{tabular}

Source: Respondents 'Answer on the Researcher made Questionnaire.

Generally, the factor average of 3.37 signifies that the administrators manifested their interpersonal roles to a very great extent. However, the two (No.2 and 3) out of six inventory items were rated at different scales, although the item average shows to a great extent.

It can be interpreted that the administrators ascertain that all dealings with their subordinates, colleagues, and superiors were held with equality and in a transparent manner $(\mu=3.17)$. It is shown that they took full responsibility for their actions, whatever were the results of their unit's performance $(\mu=3.16)$. This implies that the administrators did not hesitate to admit their mistakes if there were any without passing the blame to their subordinates to a great extent. 
In the subsequent item by item analysis, the results revealed that in the four (4) out of the six (6) inventory items, the administrators applied their managerial roles to a very great extent. They strive to create a work environment where members of the various workgroups can express themselves freely, offer ideas, and participate in many activities by promoting open communication among subordinates, peers, and superiors $(\mu=3.56)$. As things do not always conform to plans, regardless of how well an organization is managed, the administrators saw to it that contingency measures were on hand when circumstances deviate from the plans by providing an alternative approach in solving the problem $(\mu=3.39)$. The administrators, in general, were found to accept limitations and welcome constructive criticisms to enhance one's management ability $(\mu=3.49)$. This finding signified the fact that the administrators were quite open in admitting that there were limitations to contend with Hitt \& Miller, (2006) in the process of managing their department. At the same time, they were also amenable to constructive criticisms that are raised in time. They viewed them to be an avenue where they can correct their deficiencies and learned from their mistakes (W. Caseros, Interview, July 20, 2017). Finally, the administrators were found to inspire their subordinates and peers to enhance their professional and personal lives. This is manifested by helping their colleagues to attain fulfilling work and personal careers to a very great extent $(\mu=3.50)$. This means that they do not hesitate to give advice or provide support to those who were in need of it.

\section{Conceptual Managerial Role of the Academic Administrators}

Table 4 contains the data concerning the extent to which the university's academic administrators manifested their conceptual managerial roles. As shown by the factor average of 3.48 , the administrators were deemed to manifest such a role to a very great extent.

Table 4: Conceptual Managerial Role of the Academic Administrators

\begin{tabular}{|l|c|c|c|c|c|c|c|c|}
\hline \multirow{2}{*}{$\begin{array}{l}\text { Inventory Items for } \\
\text { Conceptual Roles }\end{array}$} & \multicolumn{2}{|c|}{$\begin{array}{c}\text { Teaching } \\
\text { Staff }\end{array}$} & \multicolumn{2}{c|}{$\begin{array}{c}\text { Admi } \\
\text { nistrators }\end{array}$} & $\begin{array}{c}\text { Nonteaching } \\
\text { Staff }\end{array}$ & \multicolumn{3}{c|}{$\begin{array}{c}\text { Item } \\
\text { Average }\end{array}$} \\
\cline { 2 - 10 } & $\mu$ & INT & $\mu$ & INT & $\mu$ & INT & $\mu$ & INT \\
\hline $\begin{array}{l}\text { 1. Plan the formulation for the } \\
\text { unit's objectives }\end{array}$ & 3.32 & VGE & 3.70 & VGE & 3.82 & VGE & 3.61 & VGE \\
\hline $\begin{array}{l}\text { 2. Evaluate the programs } \\
\text { submitted by individuals/groups. }\end{array}$ & 3.04 & GE & 3.60 & VGE & 3.45 & VGE & 3.36 & VGE \\
\hline $\begin{array}{l}\text { 3. Discuss with subordinates the } \\
\text { evaluation ratings and overall } \\
\text { performance. }\end{array}$ & 3.12 & GE & 3.60 & VGE & 3.45 & VGE & 3.39 & VGE \\
\hline $\begin{array}{l}\text { 4. Help subordinates in the } \\
\text { performance of their tasks }\end{array}$ & 3.11 & GE & 3.55 & VGE & 3.91 & VGE & 3.52 & VGE \\
\hline $\begin{array}{l}\text { 5.Encourage staff development } \\
\text { and training }\end{array}$ & 3.29 & VGE & 3.55 & VGE & 3.91 & VGE & 3.58 & VGE \\
\hline $\begin{array}{l}\text { 6. Review/revise plans regularly } \\
\text { as the need arises }\end{array}$ & 3.08 & GE & 3.55 & VGE & 3.73 & VGE & 3.45 & VGE \\
\hline
\end{tabular}


International Journal of Management, Entrepreneurship, Social Science and Humanities (IJMESH), Vol. 3 (2), 28-36 Managerial Roles: Intuitions of the Academic Institution Employees, an evidence from the universities in Ozamiz City

Anna C. Bocar

\begin{tabular}{|l|l|l|l|l|l|l|l|l|}
\hline $\begin{array}{l}\text { 7. Delegate responsibilities to } \\
\text { subordinates }\end{array}$ & 3.21 & GE & 3.21 & GE & 3.91 & VGE & 3.44 & VGE \\
\hline FACTOR AVERAGE & 3.17 & GE & 3.54 & VGE & 3.74 & VGE & 3.48 & VGE \\
\hline
\end{tabular}

Source: Respondents 'Answer on the Researcher made Questionnaire

In the seven (7) inventory items, the result shows that administrators applied for their managerial roles to a very great extent, as manifested by the rating of the two groups of respondents (administrators and nonteaching staff). However, the teaching staff agreed their ratings only on the two (No. 1 and 5) of the seven items. This means that on the five items, the teaching staff rated the application of academic administrators' conceptual managerial role at different levels, which is to a great extent.

Specifically, in relation to the plan in the formulation of the unit's objectives, it is indicated that the administrators spearheaded the conceptualization of the department's goals in consonance with the overall objectives of the institution to a very great extent $(\mu=3.61)$. Moreover, it can be said that they made use of acceptable standards to assess the viability of the projects recommended by their subordinates in relation to the evaluation of the programs submitted by individuals/groups $(\mu=3.36)$. It can be inferred from the results $(\mu=3.39)$ that the evaluation criteria for measuring performance were jointly agreed upon by the administrators and their subordinates. The administrators were considered highly capable of motivating their subordinates and guiding them in executing their work assignments effectively $(\mu=3.52)$. To ensure that their subordinates were able to discharge their duties well, the teaching staff, as well as nonteaching staff, need to undergo development and training. The administrators need to allocate resources appropriately to fund the various developmental schemes prepared by the department for its teachers and nonteaching staff. The respondents rated this item to a very great extent $(\mu=3.58)$. In terms of reviewing the department's plans regularly as the need arises, the result indicates that they would be able to adapt to the changes in the environment $(\mu=3.45)$. Lewis \& Goodman (2004) said that this act has a profound impact on the university's successful operations. Lastly, it can be noticed that the administrators, to a very great extent $(\mu=3.44)$, did not hesitate to transfer the responsibility for a specific activity to their subordinates and to empower them to accomplish the task effectively.

\section{Summarized Data on the Academic Administrators' Managerial Roles}

Table 5 reveals the summarized data on the extent to which the university's academic administrators manifested their various managerial roles. As revealed by the respondents, Table 5 shows that the teaching staff demonstrated a rating lower than (great extent) the ratings of the other two groups of respondents (very great extent) in all the three managerial roles of the academic administrators. However, the general average of 3.40 that is based on the general group average (3.08 from teaching staff, 3.45 from administrators, and 3.66 from nonteaching staff) implies that the administrators perform their various managerial roles to a very great extent. 
Table 5: Summarized Data on the Academic Administrators' Managerial Roles

\begin{tabular}{|l|c|c|c|c|c|c|c|c|}
\hline \multirow{2}{*}{$\begin{array}{l}\text { Three Major Areas of } \\
\text { Managerial Roles }\end{array}$} & \multicolumn{2}{|c|}{$\begin{array}{c}\text { Teaching } \\
\text { Staff }\end{array}$} & \multicolumn{2}{c|}{$\begin{array}{c}\text { Admi } \\
\text { nistrators }\end{array}$} & \multicolumn{2}{c|}{$\begin{array}{c}\text { Nonteaching } \\
\text { Staff }\end{array}$} & \multicolumn{2}{c|}{$\begin{array}{c}\text { Item } \\
\text { Average }\end{array}$} \\
\cline { 2 - 11 } Technical & $\mu$ & INT & $\mu$ & INT & $\mu$ & INT & $\mu$ & INT \\
\hline Interpersonal & 3.05 & GE & 3.41 & VGE & 3.53 & VGE & 3.33 & VGE \\
\hline Conceptual & 3.01 & GE & 3.39 & VGE & 3.72 & VGE & 3.37 & VGE \\
\hline $\begin{array}{l}\text { General Average } \\
\text { Toung }\end{array}$ & 3.17 & GE & 3.54 & VGE & 3.74 & VGE & 3.48 & VGE \\
\hline
\end{tabular}

Source: Respondents 'Answer on the Researcher made Questionnaire.

Specifically, the administrators manifested their managerial roles by showing their ability to utilized tools, techniques, and procedures specific to a particular task/field to ensure the effective operation of the department to a very great extent $(\mu=3.33)$. Likewise, they show strong human skills, which indicated their ability to work well with their subordinates and with other workgroups within the organization $(\mu=3.37)$ and exhibited the ability to analyze complex situations and respond effectively to the challenges faced by the organization. They displayed their capability of looking at the organization as a whole and understand how each group relates to each other $(\mu=3.48)$.

\section{CONCLUSIONS}

Summarize the stuffs that you had worked, findings, which findings strengthen which studies, which findings contradict which studies.

In the light of the findings of the study, the researcher concludes that although the academic administrators manifested capabilities in performing their managerial roles, in general viewpoint at a very great extent, still, there were certain areas that they needed to develop. Specifically, the academic administrators must reevaluate those items which are rated to a great extent (a rating that is a bit lower than most of the ratings) not only the teaching and nonteaching staff but also they (administrators) themselves gave such rating. These items are related to their technical, managerial roles, namely: network with other institutions and community agency, confine subordinate's workload to official duties only. The enhancement of their managerial roles in these areas would contribute more to the attainment of the goals of the university and the enhancement of their subordinates. The academic administrators also need to reassess themselves why the teaching staff's rating is often lower than the rating given by the nonteaching staff in all the areas of their managerial roles. 


\section{REFERENCES}

Campbell, R. F., Corbally J.E. and Nystraud, R.O. (2010). Introduction to Educational Administration. 6th Edition. Boston, Massachusetts.

Cunningham, W. and Cordeiro, P. (2012). Educational Leadership: A Bridge to Improved Practice (5th Edition). Boston, Massachusetts: Pearson.

Drucker, P. (2002). The Effective Executive. New York: Harper Collins

Hitt, M. and Miller, C.(2006). Organizational Behavior. Hoboken, New Jersey: John Wiley and Sons., Inc.

Katz, D. and Kahn, R. (2003). The Social Psychology of Organization. New York: Ricky and Sons Inc. Lewis, P. and Goodman, S. (2004). Management. St. Paul, Minnesota: West Publishing Company

Lunenburg, F. and Ornstein, A. (2004). Educational Administration. 4th Edition, Belmonts, CA.: Wadsworth-Thomson, Learning Inc.

March, J. and Simon, H. (2004). Organizations, 2nd edition, Cambridge, Massachuseets: Blackwell.

Peterson, K and Deal, T. (2013). How Leaders Influence the Culture of the Schools. San Francisco, CA Jossey Bass

Wright, G. (2002). Strategic Decision Making: A Best Practice Blueprint. New York: Wiley and Sons Ltd. 